\title{
CLIMATE CHANGE AND WHALE WATCHING: TOURIST'S PERCEPTION IN ISLAS MARIETAS, NAYARIT, MÉXICO
}

\author{
J. L. CORNEJO-ORTEGA ${ }^{1}$, R. M. CHÁVEZ-DAGOSTINO ${ }^{1} \&$ A. IVANOVA-BONCHEVA ${ }^{2}$ \\ ${ }^{1}$ University of Guadalajara, México. \\ ${ }^{2}$ Autonomous University of Baja California Sur, México.
}

\begin{abstract}
This paper reports upon data obtained from tourist perception research project related to whale-watching tourists during the 2010-2011 season near the Marietas Islands, off Puerto Vallarta, Mexico. In particular, questions about climate change and about the feasibility of compensation by the purchase of carbon bonds were asked. A total of 136 on-site tourist surveys were conducted to evaluate the perception of tourists about climate change. These were analyzed using SPSS statistical software. The perception of tourists is that they recognize that their actions negatively affect the marine ecosystem because of the greenhouse gas emissions produced during their touristic activities. It was acknowledged that this is especially the case for tourists who came from developed countries. It was also found that the studied tourists claim to be willing to change their lifestyle, in order to continue to have the opportunity to engage in activities such as whale watching. Additionally, they would support the purchase of carbon bonds in order to help conserve resources, mitigate, and adapt to climate change.

Keywords: Climate change, whale watching, purchase of carbon bonds and tourist's perception.
\end{abstract}

\section{INTRODUCTION}

Consequential evidence about climate change is increasing [1, 2]. Historic emissions appear to commit the Earth to some degree of future warming regardless of mitigation progress, and will likely surpass the $2^{\circ} \mathrm{C}$ threshold held by many as indicative of 'dangerous' interference $[1,3,4]$. Given a failure to create an international framework for stabilizing emissions, a $4^{\circ} \mathrm{C}$ increase in global warming by 2100 looks a possibility $[4,5]$.

Accordingly, adaptive measures for risk mitigation seem unavoidable. Interestingly, the related body of literature has focused not on perception of risk per se, but rather on evaluation of information about risk and its relation to propensity to act. Recent work [6-9] supports the assertion that in order to successfully build adaptive capacity, scientists, governments, NGOs, and other organizations must be able to communicate climate and adaptation information. They also need to establish and maintain their information's salience, credibility, and legitimacy. Critical assessment of the value of information, in turn, is influenced by the way that information is conveyed - not only by the media conveying it but also by the social relationships of those involved in its transmittal [10]. The importance of analyzing the influence of climate change on the survival of diverse cultures has been established through various cases [11-13].

The level of response to climate change has profound implications for individual choices and behavior, as well as for the social structures within which these take place. With over one-third of many developed nations' carbon emissions coming from private travel and domestic energy use [14], individuals clearly have a key role to play in any potential shift towards a low-carbon society. Besides reducing their direct emissions (e.g. conserving gas or electricity in the home), an individual can act in several roles to promote a low-carbon society. For example, being a low-carbon consumer (e.g. buying energy efficient appliances or local, seasonal food), a low-carbon employee (through professional decisions and workplace behavior), and a low-carbon citizen (e.g. voting for a 'green' policy; joining an environmental campaign or community action group). Primarily through individual 
behavior change encouraged by economic and informational approaches [15-17]. Importantly, policy proposals relying on individuals' voluntary carbon reduction highlight the need for at least some level of public understanding of the causes and consequences of carbon emissions. This needs to be matched by the ability and motivation for individuals to reduce emissions. Unfortunately, little has been done to consider the situated meanings of carbon and energy in everyday life and decisions.

The study focuses on the whale-watching industry in Bahía de Banderas and employs a surveybased approach with secondary interviews to understand the perception that whale-watching tourists have regarding the climate change. It goes on to suggest a number of mitigation measures to reduce the impact of tourism on climate change, and the potential impact of climate change on tourism. It is necessary to establish policies and guidelines to address the needs and specific opportunities to each natural area to achieve the common objectives of an integrated sustainable development of tourism in these areas. The selection of the whale-watching tourists as a study subject is due to during the winter; the main attraction is the observation of whales, humpback whales being the most important species. Small and large companies organize trips that take tourists to observe humpback whales out from various points of refuge area and in different types of boats. It is, therefore, considered that the non-extractive activity (whale watching) has great economic potential for the region. About $10 \%$ of the tourists in Bahia de Banderas go whale watching each year. This group is looking for high-quality travel (with good guides, field trips, and small groups), which costs USD \$85-\$95 per person [18]. Whale-watching activities in Mexico are performed mainly in Baja California (gray whale), Loreto and Los Cabos (blue whale), and Bahía de Banderas (humpback whale). The total estimated annual income from this activity is USD $\$ 9,077,843$ [19].

\section{BACKGROUND}

Although there is widespread global recognition of climate change, there is a general lack of knowledge and emotional engagement with the issue [20-22]. Surveys show that awareness and concern about the phenomena have increased over the past two decades [21,23], but in the context of other, more immediate or tangible concerns (e.g. health, finances), the subject takes a low priority [24]. The low relative importance reflects a wide spread perception amongst the public that the issue is a spatially and temporally remote risk, affecting future generations and other countries [25]. While it is considered socially relevant, most individuals do not feel it poses a prominent personal threat [26]. Behavioral engagement is even more limited; surveys indicate around only a third of the public is making an effort to drive or fly less [21].

When asked what actions they would be willing to undertake (or are already undertaking) to address climate change, recycling, and energy conservation in the home are the most frequently mentioned, while there is considerable resistance to changing travel habits [21, 27]. In relation to energy policies, incentives and technological solutions receive more support than taxes or higher bills $[23,28]$. One could assume that the low levels of energy conservation action are due to a lack of awareness on the part of individuals as to the most effective actions to take. Yet, while some misperceptions exist, it is striking that surveys suggest a high level of understanding amongst the public as to which behaviors contribute to the problem [21].

Recent research sheds some light on how people integrate new concepts such as climate change into existing knowledge through linguistic constructivism. Nerlich and Koteyko [29] have tracked the rise of lexical 'carbon compounds' used in the mass media to communicate climate change. The most prevalent carbon compounds they have identified relate to: finance (e.g. 'carbon tax' and 'carbon budget'); lifestyle (e.g. 'carbon footprint' and 'carbon diet'); and morality/religion (e.g. 'carbon sinner' and 'carbon indulgences'). Whitmarsh [30] found that terminology about climate change is understood in different ways and evokes diverse responses: 'global warming' is associated more 
readily with heat-related impacts, ozone depletion, and human causes than 'climate change', which is more often seem as having natural causes and a range of impacts; furthermore, 'global warming' is seen as more important and concerning than 'climate change'.

Nevertheless, exploratory research suggests that these replies can help make carbon and climate change more personally relevant and link energy choices to environmental impact; there is particular value in providing comparative information, so that individuals understand the relative contribution of different activities and how their lifestyles compare to others locally, nationally, and globally [31].

\subsection{Adaptation}

It is generally assumed that some if not enough adaptation is taking place. High-income nations are more likely to be adapting than middle- and low-income nations, unfortunately the most vulnerable are least likely to adapt. Adaptation measures are seldom undertaken in response to climate change alone, reactive adaptations are more likely in the absence of government intervention, and it is believed that the more rapid climate change is, the more problematic adaptation will be [1, 32-34]. It has also been noted that our limited understanding of vulnerability and adaptation precludes developing adaptation interventions, with more research integrating socio-economic and climate scenarios needed $[34,35]$.

Our ability to evaluate these assumptions and monitor adaptation progress, however, is constrained by an absence of measurable outcomes or indicators from which to judge if and how adaptation is occurring [36, 37]. Mitigation is a bounded problem that can be assessed with reference to the global concentration of greenhouse gases (GHGs). Adaptation is messier, concerned with adjustments in human systems at different scales (local to global) and by different actors (e.g. government, individuals, households, etc.) and which may only be partially developed in response to climatic stimuli $[38,39]$. Progress is, therefore, rarely measured, arguably contributing toward the reluctance of governments to invest in adaptive interventions [40, 41].

Adaptations include adjustments in human systems in response to actual or expected climatic stimuli or their effects, which moderates harm or exploits beneficial opportunities. Those predominantly relating to natural systems were excluded along with studies reporting mainly risk or vulnerability assessments, mitigation, general sustainable development, and conceptual or theoretical approaches. Here, a distinction between the articulation of intentions to act and adaptation actions themselves is made. Actions can include mainstreamed activities designed to address multiple motivations, but require explicit recognition of climate change as a contributing motivator [42].

Knowledge of the basic dimensions of tourism demand in relation to weather, climate, and, in particular, climate change has become in recent years a prominent subject of the study. Primarily because of the importance it can have on decision making on adaptation and mitigating climate change phenomenon by the tourism sector. Despite the methodological and technical difficulties related to the apprehension of the basic dimensions of tourism demand, the different approaches used in recent times have helped to a better understanding of this element of the tourism system in relation to atmospheric aspects [43].

\section{STUDY AREA: PARQUE NACIONAL ISLAS MARIETAS}

The Islas Marietas are situated on the coast of Nayarit state, in the municipality of Bahía de Banderas, México and were declared a natural protected area with national park status in 2005 [44], providing a total area of 1383 ha, with four core areas with a total area of 78 ha, that includes Isla Redonda, Isla Larga, and two small islands near it, a marine area located in the extreme northeast of each island, the remaining area corresponds to the marine area (Fig. 1). The scientific, educational, 


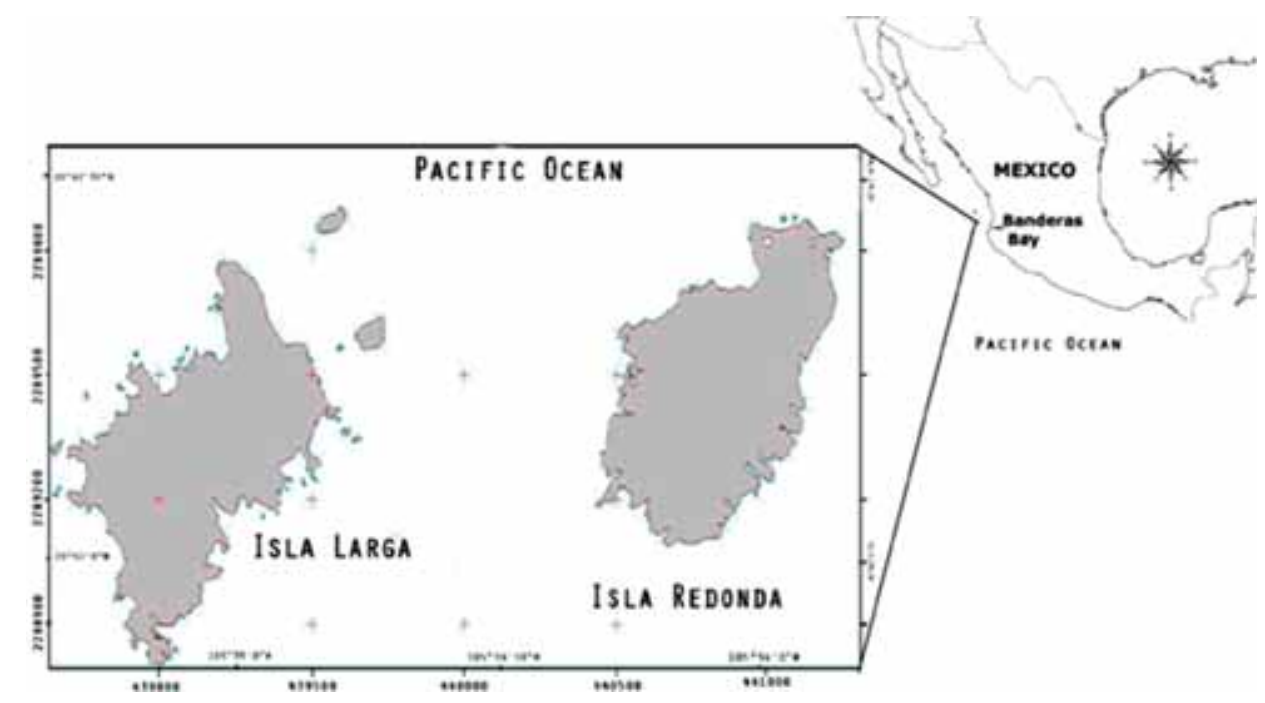

Figure 1: Islas Marietas location.

and tourism value lies in its wealth of wildlife, reproductive processes of endangered species, and scenic beauty. There is an important breeding area for marine mammals and birds, and also shelter and transit area for 92 species of birds, hosting important breeding colonies. It also includes coral reef ecosystems, which have a high diversity, large numbers of caves and tunnels, which are also the site with high diversity of reef fish in the Bahía de Banderas.

Regarding tourist importance, the Islands offer a wealth of underwater landscapes of great beauty and color, so divers have the opportunity to observe the diversity of corals, and, other invertebrates and fishes, including giant ray. Caves, rocks, and small beaches of particular scenic beauty as the Playa del Muerto and Playa La Nopalera on Isla Larga and Playa del Amor at Isla Redonda make this place so attractive to develop many activities, such as diving. During the winter, the main attraction is the whale watching, the humpback whale being the main species to exploit. Small and large companies organize trips that take tourists to observe humpback whales, coming from different parts of the area and on different types of boats. Crucially, the humpback whale in the area has great economic potential for the region [45] particularly in Bahía de Bander as where sightings are concentrated on the northern coast and mothers with calves distributed closer to the coast between Punta Mita and the Islas Marietas.

\section{METHODS}

As an initial investigation of the nature and extent of carbon capability amongst the public, we carried out a survey in December to March 2010-2011 in Puerto Vallarta, Mexico. One hundred and thirty-six questionnaires were distributed to a random sample of whale-watching visitors. The size for a simple random sample is calculated as in Fig. 2.

The two-page questionnaire included both closed and open questions, and addressed knowledge, understanding, attitudes, values, and behaviors, as well as demographic variables, in total the questionnaire consists of 14 questions (Table 1). Several of the measures used, including behavioral measures (see [46]), were adapted from previous studies like [47]. Questionnaires were piloted and revised according to feedback from pilot respondents. Quantitative data were analyzed with SPSS. 


$$
\begin{aligned}
& n_{\text {max }}=\frac{\frac{Z^{2} P Q}{\varepsilon^{2}}}{1+\frac{1}{N}\left(\frac{Z^{2} P Q}{\varepsilon^{2}}-1\right)} \approx 133 \\
& n_{\text {max }}=\text { Size for a simple random sample. } \\
& Z=1.64 \text { Trust, normal value in the normal curve abscissa. } \\
& \varepsilon= \pm 6.5 \% \text { Absolute maximum statistical error. } \\
& P=70 \%, Q=30 \% . \\
& N=78,000 \text { Tourists. }
\end{aligned}
$$

Figure 2: Sampling techiniques. (After Cochran, W.G. Sampling Techiniques (3rd ed.). USA: John Wiley \& Sons, Inc. p. 75, 1977.)

Table 1: Data and questions.

\begin{tabular}{lll}
\hline Section & & \multicolumn{1}{c}{ Data and questions } \\
\hline Respondent data & 1. Please indicate your gender \\
& 2. What year were you born? \\
3. What is the highest level of education you have attained? \\
4.
\end{tabular}

The survey was designed to be self-completed and focused on three key areas: (1) individual perceptions of climate change (2) trip characteristics and (3) demographics.

The data analysis was performed with SPSS. Descriptive statistics such as frequencies and cross tabulations were made, as was a confirmatory factor analysis. This analysis allowed the development of social research quantitative and qualitative variables. These provided the means to study the 
perception of climate change by applying a confirmatory factor model with different variables selected from the database of the survey. The confirmatory factor analysis was performed using the following steps. Initially, to raise the hypothesis the following question was formulated: What are the explanatory factors of climate change? What variables contribute more to explaining these factors? With these questions, formulation of the following hypothesis took place: the perception of the impact of humans on climate change is determined by factors related to the educational level and gender.

An analysis of commonality and variance explained was performed with commonality being a measure of the contribution of factors to explain the variables. Whilst the value is closer to one, this means that the factors completely explain the variability. The explained variance shows the percentage found by model factors or components.

\section{RESULTS}

\subsection{Tourist profile/demographics}

The results show that the vast majority of whale-watching tourists in this study are foreign citizens $(81.6 \%)$ and the rest being local tourists (18.4\%). More than 50\% are adults (older than 40 years), $52.2 \%$ are female, and $47.8 \%$ are male. The levels of education $(80.1 \%)$ are post-secondary. The majority of the respondents are from United States (55.9\%) followed by Canada (22.8\%), local tourists $(18.4 \%)$, Germany $(1.5 \%)$, and France and Colombia $(0.7 \%)$. The length of the stay was from 6 to 10 days (65.4\%), $27.2 \%$ from 1 to 5 days, and $7.4 \%$ more than 11 days, at least everybody had one meal at restaurants and bought something at a souvenir store. One other major activity that many visitors undertook was a diving tour.

\subsection{Tourist perceptions of climate change}

To understand the perception that tourists hold regarding climate change and to reveal the extent to which respondents understand the relationship between human actions (i.e. transportation and watching whales) and the perpetuation of climate change, we used the question about environmental issues in order to know how to behave with wildlife, $64.7 \%$ of the people said that the boat tour do not include discussion about environmental issues, just 35.3\% said that their tour include the discussion.

The vast majority $(83.8 \%$ ) of whale-watching tourists agreed, or strongly agreed that 'humans are contributing to changes in the global climate'. However, fewer respondents $(61 \%)$ agreed or strongly agreed with the statement 'air travel is a contributor to climate change'. These two perceptions suggest that although there is a general understanding that humans play a role in influencing the climate change, individuals do not necessarily understand how this process occurs. Even fewer respondents $(41.9 \%)$ agreed or strongly agreed with the statement 'whales will disappear from the Islas Marietas region due to changes in the global climate'. It must be stressed that only $5.1 \%$ of the respondents in this study disagreed that climate change will indeed impact whales in this region; $4.4 \%$ were simply unsure. There are studies suggesting that the whales in this region will not be drastically impacted by the climate change.

In fact, the informal, open-ended interviews conducted with whale-watching tourists during data collection for this study revealed that in many cases ( $n=10$ of 15 tourists), motivation for coming to Islas Marietas was not related to the belief that whales were in danger of disappearing. Almost half of the whale-watching tourists $(47 \%)$ indicated that 'after seeing whales [they would] make some 
changes to [their] lifestyle at home, to reduce greenhouse gas emissions'. But when we asked about what changes they plan to make the vast majority said none $(72.1 \%), 18.4$ are willing to reduce the energy use such as energy-efficient appliances, $6.6 \%$ are going to improve their environmental education, and $2.9 \%$ are going to save the water.

Only $1.5 \%$ of the respondents had purchased carbon offsets for their flight to Puerto Vallarta and an additional $37.5 \%$ indicated that they 'would be willing to pay a carbon travel tax in addition to the price of [an] airplane ticket in order to offset any environmental harm caused by air travel'. The average quantity that individuals are willing to pay to offset the GHG emissions of flight are from 5\% to $10 \%$ of the flight's price. Of those respondents who are unwilling to offset their air travel, the most commonly stated reasons include 'I do not know what the money is for' $(41.2 \%)$; 'I do not know what a carbon tax is' (4.4\%); and 'I do not know what company to trust' $(6.6 \%)$.

Participants evidently recognize the main causes of climate change, including emissions from deforestation, industry, transport, and (more generally) fossil fuel use. Misperception exists with respect to the relative contribution of different activities or processes that cause climate change. In general, people identify the causes with more 'distant' activities, namely industry and deforestation, rather than their own actions. Most also indicated that they keep an eye on the availability of energyefficient appliances $(65.6 \%)$, and on the actions that individuals can take to reduce their emissions $(80.5 \%)$. Some actions to reduce the emissions have been already performed by the survey participants. The results show that domestic energy conservation is relatively common, but changes in travel and shopping habits are less popular. For example, $80 \%$ claim that they 'always' turn off lights when they are not using, whereas only $20 \%$ walk, cycle, or take public transport for short journeys and $10 \%$ eat food that is organic, locally grown or in season. Even fewer - 9\% - avoid eating meat. Consistent with the widely reported reluctance to change travel habits [21], most participants in our survey $(82 \%)$ use a car at least three times per week; and more than $51 \%$ have taken at least one flight for social or leisure reasons in the past year. People are more willing to recycle (68\% say they always do so) than to perform any direct energy conservation actions.

On relating the four main variables with gender and educational level, the higher the education achieved the more likely is agreement with the view that humans are contributing to climate change. Also more women believe in the anthropogenic causes of climate change. Similarly, high educational achievers strongly agree (or agree) that air travel contributes to climate change. In this particular case study, men surpass women regarding the question after seeing whales. Many claim that they will make some changes to their lifestyle on returning home to reduce GHG emissions. Highest educated people strongly agree or agree, males think so too (Table 2), the interesting is that even do people agree in this, when we ask: What changes do you plan to make? In both cases (highest education and gender), the vast majority stated to have no intention to introduce any changes (Table 3).

In Table 4, we can appreciate the descriptive statistics from the main variables that we analyzed. According to the factorial analysis, gender is the variable best explained by the three factors to record the highest communalities (Table 5). The value of 0.816 is interpreted as follows: $81.6 \%$ of the variability of the genre is explained by the three factors, whereas the value of 0.056 means that the variable 'has purchased or plan to buy carbon offsets for your trip to the Marietas Islands?' is explained only by $5.6 \%$ of the three factors.

The table shows that the variance percentage model is explained by three factors or components. In the column 'rotation sums of squared loadings' shows that the first component explains $19.7 \%$ of the total variance, the second component explains $19.0 \%$, whereas the third $15.3 \%$. Thus, among the three factors $54.1 \%$ are the explained variable behavior of climate change (Table 6). 
Table 2: The percentage of high education achievers and gender in 'humans are contributing to changes in the global climate', 'air travel is a contributor to climate change', and 'after seeing whales, I will make some changes to my lifestyle at home to reduce my greenhouse gas emissions'.

\begin{tabular}{|c|c|c|c|c|c|c|}
\hline & $\begin{array}{l}\text { Strongly } \\
\text { agree }\end{array}$ & Agree & Neutral & Disagree & $\begin{array}{l}\text { Don't } \\
\text { know }\end{array}$ & Total \\
\hline \multicolumn{7}{|c|}{ 'Humans are contributing to changes in the global climate' } \\
\hline Elementary school & & & $100.00 \%$ & & & $100.00 \%$ \\
\hline High school & $52.00 \%$ & $36.00 \%$ & $12.00 \%$ & & & $100.00 \%$ \\
\hline College diploma & $29.30 \%$ & $46.30 \%$ & $22.00 \%$ & $2.40 \%$ & & $100.00 \%$ \\
\hline University degree & $41.50 \%$ & $51.20 \%$ & $7.30 \%$ & & & $100.00 \%$ \\
\hline $\begin{array}{l}\text { Graduate/professional } \\
\text { degree }\end{array}$ & $66.70 \%$ & $18.50 \%$ & $11.10 \%$ & & $3.70 \%$ & $100.00 \%$ \\
\hline Total & $44.10 \%$ & $39.70 \%$ & $14.70 \%$ & $0.70 \%$ & $0.70 \%$ & $100.00 \%$ \\
\hline Male & $41.50 \%$ & $41.50 \%$ & $13.80 \%$ & $1.50 \%$ & $1.50 \%$ & $100.00 \%$ \\
\hline Female & $46.50 \%$ & $38.00 \%$ & $15.50 \%$ & & & $100.00 \%$ \\
\hline Total & $44.10 \%$ & $39.70 \%$ & $14.70 \%$ & $0.70 \%$ & $0.70 \%$ & $100.00 \%$ \\
\hline \multicolumn{7}{|c|}{ 'Air travel is a contributor to climate change' } \\
\hline Elementary school & & & $100.00 \%$ & & & $100.00 \%$ \\
\hline High school & $12.00 \%$ & $44.00 \%$ & $32.00 \%$ & & $12.00 \%$ & $100.00 \%$ \\
\hline College diploma & $9.80 \%$ & $43.90 \%$ & $39.00 \%$ & $4.90 \%$ & $2.40 \%$ & $100.00 \%$ \\
\hline University degree & $17.10 \%$ & $56.10 \%$ & $19.50 \%$ & $7.30 \%$ & & $100.00 \%$ \\
\hline $\begin{array}{l}\text { Graduate/professional } \\
\text { degree }\end{array}$ & $14.80 \%$ & $48.10 \%$ & $22.20 \%$ & $7.40 \%$ & $7.40 \%$ & $100.00 \%$ \\
\hline Total & $13.20 \%$ & $47.80 \%$ & $29.40 \%$ & $5.10 \%$ & $4.40 \%$ & $100.00 \%$ \\
\hline Male & $13.80 \%$ & $53.80 \%$ & $24.60 \%$ & $6.20 \%$ & $1.50 \%$ & $100.00 \%$ \\
\hline Female & $12.70 \%$ & $42.30 \%$ & $33.80 \%$ & $4.20 \%$ & $7.00 \%$ & $100.00 \%$ \\
\hline Total & $13.20 \%$ & $47.80 \%$ & $29.40 \%$ & $5.10 \%$ & $4.40 \%$ & $100.00 \%$ \\
\hline \multicolumn{7}{|c|}{$\begin{array}{l}\text { 'After seeing whales, I will make some changes to my lifestyle at home to reduce } \\
\text { my greenhouse gas emissions' }\end{array}$} \\
\hline Elementary school & & & $100.00 \%$ & & & $100.00 \%$ \\
\hline High school & $8.00 \%$ & $28.00 \%$ & $52.00 \%$ & & $12.00 \%$ & $100.00 \%$ \\
\hline College diploma & $4.90 \%$ & $39.00 \%$ & $39.00 \%$ & $7.30 \%$ & $9.80 \%$ & $100.00 \%$ \\
\hline University degree & $19.50 \%$ & $36.60 \%$ & $24.40 \%$ & $4.90 \%$ & $14.60 \%$ & $100.00 \%$ \\
\hline $\begin{array}{l}\text { Graduate/professional } \\
\text { degree }\end{array}$ & $11.10 \%$ & $40.70 \%$ & $25.90 \%$ & $11.10 \%$ & $11.10 \%$ & $100.00 \%$ \\
\hline Total & $11.00 \%$ & $36.00 \%$ & $35.30 \%$ & $5.90 \%$ & $11.80 \%$ & $100.00 \%$ \\
\hline Male & $15.40 \%$ & $38.50 \%$ & $27.70 \%$ & $4.60 \%$ & $13.80 \%$ & $100.00 \%$ \\
\hline Female & $7.00 \%$ & $33.80 \%$ & $42.30 \%$ & $7.00 \%$ & $9.90 \%$ & $100.00 \%$ \\
\hline Total & $11.00 \%$ & $36.00 \%$ & $35.30 \%$ & $5.90 \%$ & $11.80 \%$ & $100.00 \%$ \\
\hline
\end{tabular}


Table 3: The percentage of high education achievers and gender in 'What changes do you plan to make'.

\begin{tabular}{lrrrrr}
\hline & Energy & Water & $\begin{array}{l}\text { Environmental } \\
\text { education }\end{array}$ & None & Total \\
\hline $\begin{array}{l}\text { What changes do you plan to make? } \\
\text { Elementary school }\end{array}$ & & & & \\
High school & $8.00 \%$ & & $100.00 \%$ & $100.00 \%$ \\
College diploma & $19.50 \%$ & $2.40 \%$ & & $80.00 \%$ & $100.00 \%$ \\
University degree & $24.40 \%$ & $7.30 \%$ & $4.90 \%$ & $63.40 \%$ & $100.00 \%$ \\
Graduate/professional degree & $18.50 \%$ & & $14.80 \%$ & $66.70 \%$ & $100.00 \%$ \\
Total & $18.40 \%$ & $2.90 \%$ & $6.60 \%$ & $72.10 \%$ & $100.00 \%$ \\
Male & $18.50 \%$ & $4.60 \%$ & $6.20 \%$ & $70.80 \%$ & $100.00 \%$ \\
Female & $18.30 \%$ & $1.40 \%$ & $7.00 \%$ & $73.20 \%$ & $100.00 \%$ \\
Total & $18.40 \%$ & $2.90 \%$ & $6.60 \%$ & $72.10 \%$ & $100.00 \%$ \\
\hline
\end{tabular}

Table 4: Descriptive statistics.

\begin{tabular}{|c|c|c|c|c|c|c|}
\hline & $N$ & Minimum & Maximum & Mean & $\begin{array}{l}\text { Standard } \\
\text { deviation }\end{array}$ & Variance \\
\hline $\begin{array}{l}\text { 'Humans are contributing to } \\
\text { changes in the global climate' }\end{array}$ & 136 & 1 & 6 & 1.75 & 0.823 & 0.678 \\
\hline $\begin{array}{l}\text { 'Air travel is a contributor to } \\
\text { climate change' }\end{array}$ & 136 & 1 & 6 & 2.44 & 1.073 & 1.152 \\
\hline $\begin{array}{l}\text { 'After seeing whales, I will make } \\
\text { some changes to my lifestyle at } \\
\text { home to reduce my greenhouse } \\
\text { gas emissions' }\end{array}$ & 136 & 1 & 6 & 2.83 & 1.380 & 1.905 \\
\hline $\begin{array}{l}\text { What changes do you plan to } \\
\text { make? }\end{array}$ & 136 & 1 & 4 & 3.32 & 1.179 & 1.391 \\
\hline $\begin{array}{l}\text { Did you purchase, or do you } \\
\text { plane to purchase carbon offset } \\
\text { for your travel to Islas Marietas? }\end{array}$ & 136 & 1 & 2 & 1.99 & 0.121 & 0.015 \\
\hline Gender & 136 & 1 & 2 & 1.52 & 0.501 & 0.251 \\
\hline Highest level of education & 136 & 1 & 5 & 3.49 & 1.054 & 1.111 \\
\hline
\end{tabular}

Extraction method: principal component analysis.

Eigen's values are the numerical expression of the components, explaining its value as a percentage of the total variance. For example, in the 'rotation sums of squared loadings' eigen's value of 1384 corresponds to $19.7 \%$, whereas eigen values of 1.332 and 1.073 explain $19.0 \%$ and $15.3 \%$, respectively. The variation increases in direct relationship to the magnitude of eigen value. Thus, the above three eigen values explain almost $54.1 \%$ of the total variability of the model. This is an acceptable percentage, with three factors responsible for about half the climate change variation. 
Table 5: Commonalities.

\begin{tabular}{lcc}
\hline & Initial & Extraction \\
\hline 'Humans are contributing to changes in the global climate' & 1.000 & 0.625 \\
'Air travel is a contributor to climate change' & 1.000 & 0.691 \\
'After seeing whales, I will make some changes to my lifestyle at & 1.000 & 0.679 \\
home to reduce my greenhouse gas emissions' & & \\
What changes do you plan to make? & 1.000 & 0.689 \\
$\begin{array}{l}\text { Did you purchase, or do you plane to purchase carbon offset for your } \\
\text { travel to Islas Marietas? }\end{array}$ & 1.000 & 0.056 \\
Gender & 1.000 & 0.816 \\
Highest level of education & 1.000 & 0.234 \\
\hline
\end{tabular}

Extraction method: principal component analysis.

Table 6: Explained variance percentage.

\begin{tabular}{|c|c|c|c|c|c|c|c|c|c|}
\hline \multirow[b]{2}{*}{ Component } & \multicolumn{3}{|c|}{ Initial eigen values } & \multicolumn{3}{|c|}{$\begin{array}{l}\text { Extraction sums of } \\
\text { squared loadings }\end{array}$} & \multicolumn{3}{|c|}{$\begin{array}{l}\text { Rotation sums of } \\
\text { squared loadings }\end{array}$} \\
\hline & Total & $\begin{array}{c}\% \text { of } \\
\text { variance }\end{array}$ & $\begin{array}{c}\text { Cumulative } \\
\%\end{array}$ & Total & $\begin{array}{c}\% \text { of } \\
\text { variance }\end{array}$ & $\begin{array}{c}\text { Cumulative } \\
\%\end{array}$ & Total & $\begin{array}{c}\% \text { of } \\
\text { variance }\end{array}$ & $\begin{array}{c}\text { Cumulative } \\
\%\end{array}$ \\
\hline 1 & 1.592 & 22.738 & 22.738 & 1.592 & 22.738 & 22.738 & 1.384 & 19.767 & 19.767 \\
\hline 2 & 1.127 & 16.095 & 38.833 & 1.127 & 16.095 & 38.833 & 1.332 & 19.035 & 38.802 \\
\hline 3 & 1.071 & 15.300 & 54.134 & 1.071 & 15.300 & 54.134 & 1.073 & 15.331 & 54.134 \\
\hline 4 & 1.034 & 14.774 & 68.908 & & & & & & \\
\hline 5 & .927 & 13.239 & 82.147 & & & & & & \\
\hline 6 & .684 & 9.773 & 91.920 & & & & & & \\
\hline 7 & .566 & 8.080 & 100.000 & & & & & & \\
\hline
\end{tabular}

Extraction method: principal component analysis.

In Fig. 3, the abscissa axis represents the number of factors or components, and the ordinate numerical value. The graph shows the inverse relationship between the magnitude of the coefficient and the number of factors. Since the magnitude of the coefficient measures the explanatory power, inferred is that more factors are calculated as the explanatory power decreases. The turning point of the curve indicates the ideal number of factors to determine. In this case, the chart confirms that the ideal number of factors is 2 .

Table 7 shows the correlation between the variable and the component. What changes do you plan to make? Is the variable with the better correlation with component one (0.677), 'Humans are contributing to changes in the global climate' with second component (0.640), and Gender with component three (0.884). 


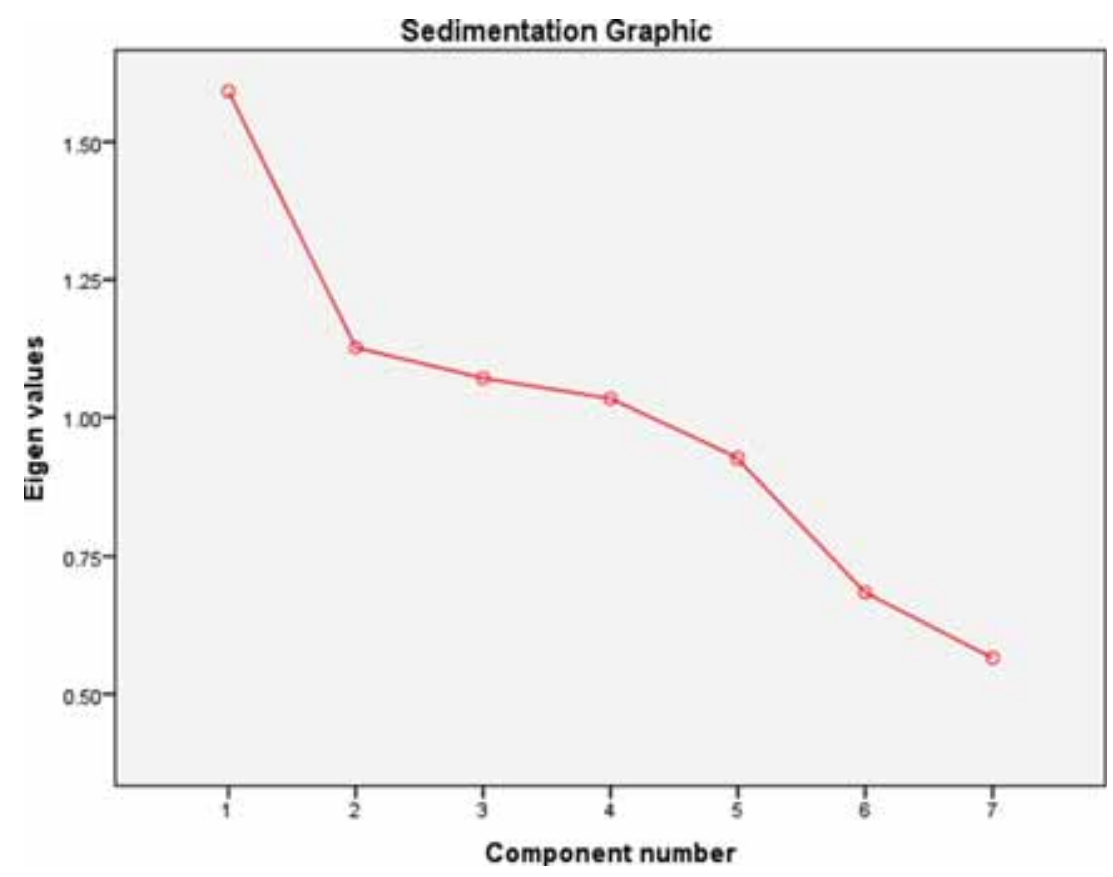

Figure 3: Sedimentation graphic. Source: extraction method: principal component analysis.

Table 7: Component matrix. ${ }^{\mathrm{a}}$

\begin{tabular}{lrrr}
\hline & \multicolumn{3}{c}{ Component } \\
\cline { 2 - 4 } & 1 & 2 & 3 \\
\hline What changes do you plan to make? & 0.677 & -0.470 & 0.098 \\
'After seeing whales, I will make some changes to my lifestyle & 0.658 & -0.495 & 0.029 \\
at home to reduce my greenhouse gas emissions' & & & \\
'Humans are contributing to changes in the global climate' & -0.556 & 0.418 & -0.375 \\
Highest level of education & -0.222 & 0.193 \\
'Humans are contributing to changes in the global climate' & 0.480 & 0.640 & 0.227 \\
Gender & 0.109 & 0.148 & 0.884 \\
Did you purchase, or do you plane to purchase carbon offset for & 0.033 & 0.071 & -0.222 \\
your travel to Islas Marietas? & & & \\
\hline Extraction ma
\end{tabular}

Extraction method: principal component analysis.

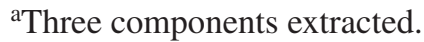

\section{DISCUSSION}

Whale-watching tourists in this study seem to have a general understanding of the presence and potential consequences of climate change including negative impacts. Only $0.7 \%$ of tourists did not feel that humans are contributing to changes in the global climate. Conversely, some evidence suggests that because whales are seemingly vulnerable to climate change, this motivates tourists to 
travel to Bahia de Banderas to watch the species 'before it is too late'. Although it is too early to call this type of tourist behavior a 'trend', the phenomenon of 'last chance tourism' has also been documented in popular media and by tourism academics. Last chance tourism has been extensively labeled. These include 'see it before it's gone tourism', 'doom tourism', 'dooms day tourism', 'climate tourism' and 'disappearing destinations tourism' [48, 49]. An increase in this type of tourism activity (i.e. see it before it is gone), which has been observed within this study, is likely to add strain to the environment (both human and ecological) that is already stressed by the effects of climate change.

Whale-watching tourists appear to understand how their behavior contributes to, or could help to adapt to and mitigate, future climate change. Some $60 \%$ of the respondents strongly agree or agree that air transportation contributes to climate change, and the rest $(37.5 \%)$ expressed a willingness to buy carbon offsets for their holiday transportation emissions. A significant barrier to the latter is an almost complete absence of knowledge as to what a carbon offset actually is, how the money is used to mitigate the climate change, and which companies are reliable in delivering the promised outcome.

Only $47 \%$ of tourists indicated that after seeing whales they would introduce some changes to their lifestyle at home in order to reduce GHG emissions. Contradictorily, $72 \%$ of the respondents said that they are not going to do any changes. These findings suggest that a climate change education on the impact of climate change on whales as well as strategies to reduce GHGs that cause climate change should be included during regular whale-watching tours.

Importantly in this context, relevant information is individually and socially contextualized. Yet, these concepts and tools will not necessarily lead to behavior change when individuals are not motivated to change or perceive barriers to do so. Indeed, amongst users of carbon calculators, many (though by no means all) use such tools to offset their emissions rather than to change their energy consumption behavior [31]. In some cases, these tools only serve to highlight the lack of individual control over potentially major carbon-saving actions (e.g. lack of insulation in rented accommodation), and the minimal effect of other, directly controllable, choices (e.g. using energy-efficient light bulbs). Clearly, information provision of any kind, even packaged in a personally relevant, userfriendly, and contextualized form, cannot address competing values or the wider, structural barriers to low-carbon lifestyles mentioned above.

The main findings from the factorial analysis model have revealed that the variables conditioning the perception of climate change situation are: air transport is a contributor to climate change and gender (those which have the highest weight or factor loading each factor). The identification of these dimensions and the consistency of the model and data allow the analysis of the results from them without resorting to original variables. Another measure of quality is the values shown in the table of commonality. This table shows the percentage of the behavior of the variable that is explained by the estimated factors. In this case, the variable 'gender' is explained in the three factors in more than $80 \%$; on the other hand, educational level does not reach $25 \%$ in the three factors. With this we confirm our hypothesis.

\section{CONCLUSION}

Many of those responding to the research questions came from developed countries such as the USA and Canada. But majority believed that their everyday life style have negative effects, which can contribute to global climate change. Encouragingly many appeared willing to assuage their activities with the purchase of carbon offsetting in order to generate resources for mitigation and adaptation applications. The resultant measures being offered or applied in areas of population are affected by activities that generate carbon dioxide emissions. Unfortunately, almost all of the respondents agreed 
that there is lack of information regarding the use of the resources generated by the purchase of carbon offsetting bonds. This makes it difficult for them to judge to respond appropriately because they do not know what happens to the resources and who the most reliable company are to manage these resources.

Some commentary required regarding 'developed' country attitudes do they become more concerned as the wealth of the nation and individuals increase. If so does this bode well for developing countries?

Finally, the research shows that there is awareness of the global damage generated through activities such as whale watching by those who travel a considerable distances to carry it out. It also indicates that most people are willing to contribute either directly by purchasing carbon bonds or making a change in their lifestyle to help mitigate and adapt to climate change. These two factors offer an insight into motivations and the potential direction needed for those seeking to engender mitigation strategies into tourism activities that impact on the natural world and its biodiversity.

\section{REFERENCES}

[1] Smith, J.B., Schneider, S.H., Oppenheimer, M., et al., Assessing dangerous climate change through an update of the Intergovernmental Panel on Climate Change (IPCC) "reasons for concern". Proceedings of the National Academy Science USA, 106, pp. 4133-4137, 2009. doi: http://dx.doi.org/10.1073/pnas.0812355106

[2] Fussel, H.M., An updated assessment of the risks from climate change based on research published since the IPCC Fourth Assessment Report. Climate Change, 97, pp. 469-482, 2009. doi: http://dx.doi.org/10.1007/s10584-009-9648-5

[3] Ramanathan, V. \& Feng, Y., On avoiding dangerous anthropogenic interference with the climate system: formidable challenges ahead. Proceedings of the National Academy Science USA, 105, pp. 14245-14250, 2008. doi: http://dx.doi.org/10.1073/pnas.0803838105

[4] Parry, M., Lowe, J. \& Hanson, C., Overshoot, adapt and recover. Nature, 458, pp. 1102-1103, 2009. doi: http://dx.doi.org/10.1038/4581102a

[5] Adger, W.N. \& Barnett, J., Four reasons for concern about adaptation to climate change. Environment and Planning A, 41, pp. 2800-2805, 2009. doi: http://dx.doi.org/10.1068/a42244

[6] Cash, D., Clark, W.C., Alcock, F., Dickson, N., Eckley, N. \& Jäger, J., Salience, credibility, legitimacy and boundaries: linking research, assessment and decision making. KSG Working Papers Series RWP02-046, 2002. Available at SSRN: http://ssrn.com/abstract=372280 or doi:10.2139/ssrn.372280 doi: http://dx.doi.org/10.2139/ssrn.372280

[7] Cash, D., Clark, W.C., Alcock, F., Dickson, N., Eckley, N., Guston, D.H., Jäger, J. \& Mitchell, R.B., Knowledge systems for sustainable development. Proceedings of the National Academy of Sciences USA, 100, pp. 8086-8091, 2003. doi: http://dx.doi.org/10.1073/pnas.1231332100

[8] Meinke, H., Nelson, R., Kokic, P., Stone, R., Selvaraju, R. \& Baethgen, W., Actionable climate knowledge: from analysis to synthesis. Climate Research, 33, pp. 101-110, 2006. doi: http:// dx.doi.org/10.3354/cr033101

[9] Vogel, C., Moser, S.C., Kasperson, R.E. \& Dabelko, G.D., Linking vulnerability, adaptation, and resilience science to practice: pathways, players, and partnerships. Global Environmental Change, 17, pp. 349-364, 2007. doi: http://dx.doi.org/10.1016/j.gloenvcha.2007.05.002

[10] Stapel, D., Reicher, S. \& Spears, R., Social identity, availability, and the perception of risk. Social Cognition, 12, pp. 1-17, 1994. doi: http://dx.doi.org/10.1521/soco.1994.12.1.1

[11] Berkes, F. \& Jolly, D., Adapting to climate change: social-ecological resilience in a Canadian western arctic community. Conservation Ecology, 5, p. 18, 2001. 
[12] Crate, S.A., Gone the bull of winter? Contemplating climate change's cultural implications in northeaster Siberia, Russia. Anthropology and Climate Change: From Encounters to Actions, eds, S.A. Crate \& M. Nuttall, Left Coast Press Inc.: California, pp. 139-152, 2009.

[13] Crate, S.A. \& Nuttall, M., Introduction: anthropology and climate change. Anthropology and Climate Change: From Encounters to Actions, eds. S.A. Crate \& M. Nuttall, Left Coast Press Inc.: California, pp. 9-36, 2009.

[14] DEFRA, Key facts about: climate change. Emissions of greenhouse gases: 1990-2006 (provisional) UK, available at: www.defra.gov.uk/environment, 2007a, (accessed 15 November 2011).

[15] HM Government, The UK low carbon transition plan. National strategy for climate and energy. London, available at: www.decc.gov.uk/en, 2009 (accessed 25 October 2011).

[16] Hinchliffe, S., Helping the earth begins at home: the social construction of socio-environmental responsibilities. Global Environmental Change, 6, pp. 53-62, 1996. doi: http://dx.doi. org/10.1016/0959-3780(95)00113-1

[17] Ockwell, D., Whitmarsh, L. \& O'Neill, S., Reorienting climate change communication for effective mitigation-forcing people to be green or fostering grassroots engagement? Science Communication, 30(3), pp. 305-327, 2009. doi: http://dx.doi.org/10.1177/1075547008328969

[18] Hoyt, E. \& Iñíguez, M., Estado del Avistamiento de Cetáceos en América Latina. WDCS, Chippenham, UK; IFAW, East Falmouth, EE.UU.; y Global Ocean, Londres, 60p, 2008.

[19] Frisch, J.A., La ballena jorobada y la observación de ballenas en bahía de Banderas. CONABIO. Biodiversitas, 86, pp. 1-6, 2009.

[20] BBC World Service, All countries need to take major steps on climate change: global poll, available at: http://news.bbc.co.uk, 2007 (accessed 25 November 2011).

[21] DEFRA, Survey of Public Attitudes and Behaviours toward the Environment, 2007. Department for Environment, Food and Rural Affairs: London, 2007b.

[22] Lorenzoni, I., Nicholson-Cole, S. \& Whitmarsh, L., Barriers perceived to engaging with climate change among the UK public and their policy implications. Global Environmental Change, 17, pp. 445-459, 2007. doi: http://dx.doi.org/10.1016/j.gloenvcha.2007.01.004

[23] DEFRA, Survey of Public Attitudes to Quality of Life and to the Environment-2001. DEFRA: London, 2002.

[24] Poortinga, W. \& Pidgeon, N., Public Perception of Risk, Science and Governance. University of East Anglia and MORI: Norwich, 2003.

[25] O'Neill, S.J. \& Hulme, M., An iconic approach for representing climate change. Global Environmental Change, 19, pp. 402-410, 2009. doi: http://dx.doi.org/10.1016/j.gloenvcha.2009.07.004

[26] Bord, R.J., O'Connor, R.E. \& Fisher, A., In what sense does the public need to understand global climate change? Public Understanding of Science, 9, pp. 205-218, 2000. doi: http:// dx.doi.org/10.1088/0963-6625/9/3/301

[27] Whitmarsh, L., Behavioural responses to climate change: asymmetry of intentions and impacts. Journal of Environmental Psychology, 29, pp. 13-23, 2009. doi: http://dx.doi.org/10.1016/j.jenvp.2008.05.003

[28] O'Connor, R.E., Bord, R.J. \& Fisher, A., Risk perceptions, general environmental beliefs, and willingness to address climate change. Risk Analysis, 19, pp. 461-471, 1999. doi: http://dx.doi. org/10.1111/j.1539-6924.1999.tb00421.x

[29] Nerlich, B. \& Koteyko, N., Compounds, creativity and complexity in climate change communication: the case of 'carbon indulgences'. Global Environmental Change, 19, pp. 345-353, 2009. doi: http://dx.doi.org/10.1016/j.gloenvcha.2009.03.001

[30] Whitmarsh, L., What's in a name? Commonalities and differences in public understanding of 'climate change' and 'global warming'. Public Understanding of Science, 18, pp. 401-420, 2009. doi: http://dx.doi.org/10.1177/0963662506073088 
[31] DfT, Exploring public attitudes to personal carbon dioxide emission information. Report for the Department of Transport by BMRB Social Research, Centre for Transport \& Society and the Air Quality Management Resource Centre, 2007.

[32] Stern, N., Stern Review on the Economics of Climate Change. HM Treasury: London, UK, 2006.

[33] IPCC, IPCC Fourth Assessment Report (AR4): Climate Change 2007. Contribution of Working Groups I, II and III to the Fourth Assessment Report of the Intergovernmental Panel on Climate Change. Cambridge University Press: Cambridge, UK, 2007.

[34] World Bank, World Development Report - Development and Climate Change. World Development Report: Washington, DC, 2010.

[35] Moss, R.H., Edmonds, J.A., Hibbard, K.A., et al., The next generation of scenarios for climate change research and assessment. Nature, 463, pp. 747-756, 2010. doi: http://dx.doi. org/10.1038/nature08823

[36] Burton, I. \& May, E., The adaptation deficit in water resource management. IDS Bulletin: Institute of Development Studies, 35, p. 31, 2004. doi: http://dx.doi.org/10.1111/j.1759-5436.2004.tb00131.x

[37] Gagnon-Lebrun, F. \& Agrawala, S., Implementing adaptation in developed countries: an analysis of progress and trends. Climate Policy, 7, pp. 392-408, 2007. doi: http://dx.doi.org/10.108 0/14693062.2007.9685664

[38] Berkhout, F., Rationales for adaptation in EU climate change policies. Climate Policy, 5, pp. 377-391, 2005. doi: http://dx.doi.org/10.1080/14693062.2005.9685564

[39] Dovers, S. \& Hezri, R., Institutions and policy processes: the means to the ends of adaptation. WIREs: Climate Change, 1, pp. 212-231, 2010.

[40] Burton, I., Huq, S., Lim, B., et al., From impacts assessment to adaptation priorities: the shaping of adaptation policy. Climate Policy, 2, pp. 145-159, 2002. doi: http://dx.doi.org/10.3763/cpol.2002.0217

[41] Pielke, R.A., Rethinking the role of adaptation in climate policy. Global Environmental Change: Human Policy Dimensions, 8, pp. 159-170, 1998. doi: http://dx.doi.org/10.1016/ S0959-3780(98)00011-9

[42] Berrang-Ford,L.,Ford,J.D. \& Paterson,J.,Are we adapting toclimatechange? Global Environmental Change, 21, pp. 25-33, 2011. doi: http://dx.doi.org/10.1016/j.gloenvcha.2010.09.012

[43] Gómez Martín, Belén M. \& Martínez Ibarra, E., Approach to a new methodology to study tourism demand in relation with climate (submitted).

[44] DOF, Decreto por el que se declara área natural protegida, con la categoría de parque nacional, la región Islas Marietas. Diario Oficial de la Federación [online] SEGOB, Mexico [2005-04-25]. Available at: http://dof.gob.mx, 2005 (accessed 26 August 2011).

[45] Lugo Cabrera, E. \& Rodríguez-Vázquez, M.E., Etograma de la ballena jorobada en Bahía de Banderas, México. Resúmenes XXV Reunión internacional para el estudio de los mamíferos marinos. La Paz, BCS. p. 57, 2000.

[46] DEFRA, A Framework for Pro-Environmental Behaviours. Department for Environment Food and Rural Affairs: London, 2008.

[47] Dawson, J., Stewart, E.J, Lemelin, H. \& Scott, D., The carbon cost of polar bear viewing tourism in Churchill, Canada. Journal of Sustainable Tourism, 18(3), pp. 319-336, 2010. doi: http://dx.doi.org/10.1080/09669580903215147

[48] Brock, P., The town that can't wait for the world to warm up. The Sunday Times Magazine, pp. 40-45, available at: http://www.timesonline.co.uk/tol/news/environment/article3362887. ece, 2008 (accessed 17 February 2008).

[49] Lemelin, R.H., \& Johnson, M., Northern protected areas and parks. Parks and Protected Areas in Canada: Planning and Management, 3rd edn., eds. P. Dearden \& R. Rollins, Oxford University Press: New York, 2008. 